\title{
Har økonomisk politikk gjort Saudi-Arabia mer robust overfor fremtidige sjokk?
}

Ulikt flere andre land i Midtøsten har ikke Saudi-Arabia blitt rammet av omfattende politisk uro. Økonomisk vekst og aktiv velferdspolitikk kan ha bidratt til en mer stabil politisk situasjon. Krig og misnøye i deler av Midtøsten kan imidlertid spre seg til Saudi-Arabia og true stabiliteten.

Av Ådne Cappelen og Robin Choudhury, Statistisk sentralbyrå.

DE OLJERIKE GULFSTATENE har ikke unnsluppet «den arabiske våren». Det har vært protester i Kuwait, og i Bahrain førte demonstrasjoner til at monarken måtte be om tropper fra SaudiArabia for å få slutt på protestene. Ifølge flere kommentatorer skiller de oljerike Gulfstatene seg ut fra andre land i Midtøsten og Nord-Afrika (MøNA-regionen). The Economist skrev (13. juli 2013) at liten befolkning og voksende velstand har gjort disse landene i stand til å «buy a holiday from politics», men de har likevel måttet slå hardt ned på uttrykt dissens.

I Saudi-Arabia har protestene vært mer dempet, men omveltningene i regionen har påvirket politikken der også. De senere årenes trend med økonomiske reformer og relativ forsiktig pengebruk, endret seg i begynnelsen av 2011 da kongefamilien ble bekymret for at opptøyene skulle spre seg til landet. For å motvirke misnøye annonserte de, gjennom 41 kongelige dekreter, et utgiftsprogram til en verdi av 129 milliarder dollar. Offentlige ansatte ble gitt to måneders ekstra lønn, det ble vedtatt arbeidsledighetstrygd tilsvarende 533 dollar per måned, det ble opprettet 60 ooo nye stillinger i innenriksdepartementet, og 67 milliarder dollar ble allokert til boligbygging. ${ }^{1}$

En slik respons fra myndighetenes side er hva man kunne forvente med utgangspunkt i litteratur om politisk økonomi i ressursrike økonomier. ${ }^{2,3}$ Men for Saudi-Arabias vedkommende, et land som har hatt et kontinuerlig regime uten noen omveltninger siden staten ble opprettet, kan man ikke identifisere effekter av ressurssituasjonen på den politiske situasjonen til forskjell fra landspesifikke faktorer. Dette er en svakhet med svært mye av den empiriske litteraturen på feltet. Man kan ikke forvente særlig robuste resultater fra bare å studere et tverrsnitt av land, og i noen 
tilfeller er det mer fruktbart å studere variasjoner over tid innad i et ressursrikt land, slik vi gjør i denne artikkelen.

I denne artikkelen ser vi på den økonomiske utviklingen i Saudi-Arabia, og spesielt på sårbarheten med tanke på et potensielt stort fall i oljeprisen. Hvis man er enig med The Economist og politisk økonomi-litteraturen om at oljerikdommen er sentral for den politiske stabiliteten i Saudi-Arabia, er det vel verdt å forsøke å identifisere mer nøyaktig de inntektene og ressursene landet trenger i fremtiden for å balansere sine budsjetter og utgifter. I denne forstand er studien en oppfølging av tidligere studier. ${ }^{4,5}$

\section{Saudi-arabisk økonomi}

Sammenlignet med mindre oljerike arabiske land fremstår mange av Culfstatene som rike målt ved BNP per innbygger (i kjøpekraftsjusterte USD). Ser vi bort fra Qatar med sitt ekstremt høye inntektsnivå, har Saudi-Arabia et inntektsnivå som er omtrent 90 prosent av gjennomsnittlig oECD-nivå, og Kuwaits er enda høyere. ${ }^{6}$ Til sammenligning var det norske nivået 1,8 ganger høyere enn det gjennomsnittlige OECD-nivået i 2012.

Ser vi på andre MøNA-land er inntektsnivåene betydelig lavere.7 Disse landene har inntektsnivåer som er mindre enn halvparten av hva de oljerike landene har. Det synes imidlertid ikke å være noen klar sammenheng mellom inntektsnivå og politisk uro. For eksempel, i både Libya og Tunisia har inntektsnivået økt ganske mye etter 2000 , og er relativt høyt sammenliknet med mange land i regionen. Likevel har man ikke klart å unngå politisk uro. Marokko, derimot, har lav inntekt per innbygger, men her reagerte kongen raskt da den politiske uroen oppsto, og gjorde endringer $\mathrm{i}$ grunnloven som roet den politiske situasjonen.

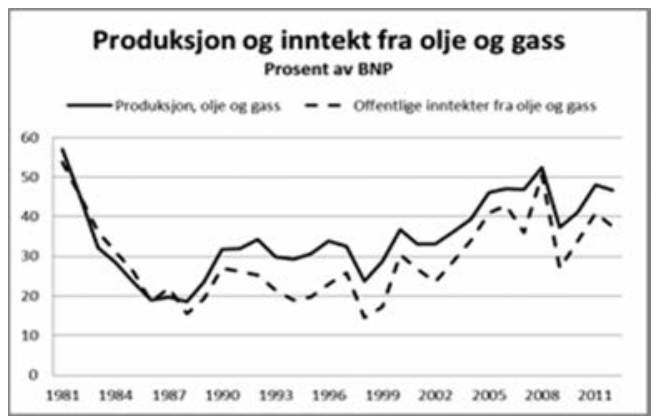

Figur 1. Kilde: Saudi Arabian Monetary Agency (årsrapporter), Central Department of Statistics and Information.

Hvis BNP per innbygger, om enn bare svakt, er korrelert med politisk uro i disse landene i senere tid, er det da noe med nivået eller trendene $\mathrm{i}$ inntektsfordelingen som indikerer et potensial for sosial uro? Ifølge Verdensbanken var antallet mennesker som lever på mindre enn 1,25 dollar per dag (i kjøpekraftsjusterte priser) i møNA-regionen som helhet stabil i 1990-årene, og det ble halvert i løpet av det forrige tiåret. ${ }^{8}$

Sammenlignet med de fleste andre regioner $i$ verden er ikke fordelingen av inntekt og forbruk mer ulik i MøNA-land, og det har ikke vært noen dramatisk endring $\mathrm{i}$ årene frem til den arabiske våren.

Oljesektoren dominerer den saudiske økonomien. I 2012 utgjorde produksjon av råolje og naturgass 47 prosent av BNP. Produksjon av offentlige tjenester, som nesten helt er finansiert av oljeinntektene, var 12,7 prosent av BNP i 2012. I tillegg er mange av aktivitetene i privat sektor, som for eksempel varehandel og bolig, indirekte finansiert av oljeinntektene. ${ }^{9}$ Historisk har oljeproduksjonen som andel av BNP variert mye på grunn av endringer i oljeprisen (se Figur 1).

Det er vanlig å hevde at en overdreven statlig regulering og mangel på åpenhet $\mathrm{i}$ økonomisk samkvem med andre land, har ført lav økonomisk vekst i mange arabiske land. ${ }^{\circ}$ 


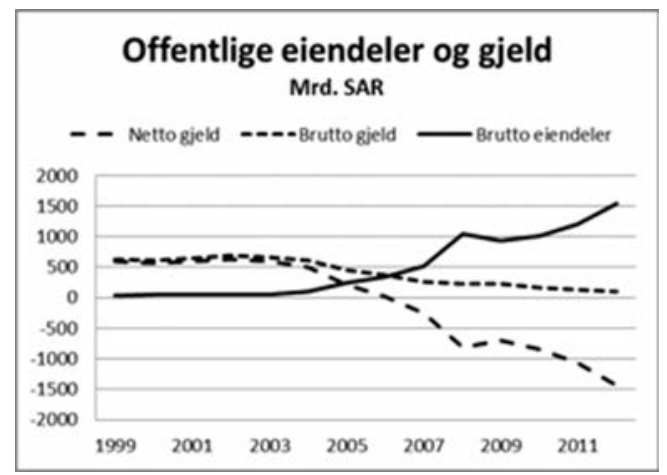

Figur 2. Kilde: International Monetary Fund, World Economic Outlook Database, April 2013.

Veksten i privat sektor utenom olje har vært sterkere enn i oljesektoren og i offentlig sektor det siste tiåret. ${ }^{11}$ Dette indikerer at den saudiske økonomien har diversifisert seg i de senere årene. En slik endring i næringsstrukturen har vært et politisk mål for myndighetene i lang tid. ${ }^{12}$ Fordi global etterspørsel etter olje har økt lite, har det vært lite rom for vekst i Saudi-Arabia gjennom økt oljeproduksjon. I stedet har vekten ligget på å

Veksten i privat sektor har vert sterkere enn i oljesektoren og i offentlig sektor det siste tiåret.

$$
\infty
$$

diversifisere økonomien over mot privat sektor for å opprettholde levestandarden, samt å sørge for at unge mennesker får muligheter på arbeidsmarkedet.

Oljens dominerende rolle gir seg også utslag i sammensetningen av statens inntekter. I 2012 utgjorde oljeinntektene 91,8 prosent av statens totale inntekter. Dermed er bare 8,2 prosent av statsinntektene knyttet til ikke-oljerelaterte kilder, hvorav mesteparten stammer fra importavgifter. Budsjettoverskuddet beløp seg til 374 milliarder saudiske riyaler (SAR), eller 14

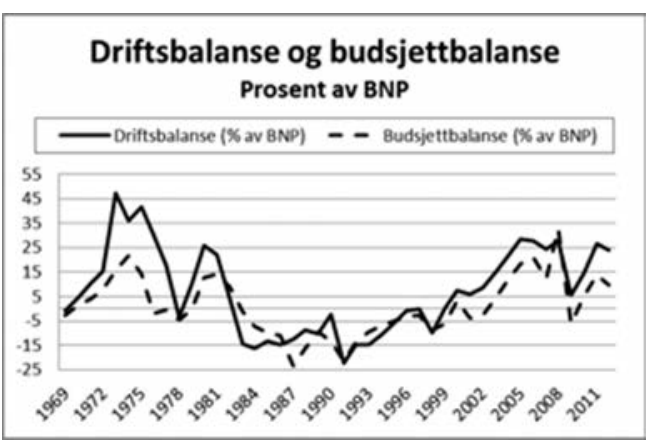

Figur 3. Kilde: Central Department of Statistics and Information og Saudi Arabian Monetary Agency.

prosent av BNP, og utgiftene til 31,7 prosent $\mathrm{i}$ 2012. ${ }^{13}$ Dette betyr at myndighetene nå sparer en stor andel av de løpende inntektene, noe de har gjort i flere år. Frem til 2006 hadde saudiske myndigheter positiv nettogjeld (dvs. bruttogjeld var større enn finansielle eiendeler), men deretter har de akkumulert netto fordringer, som i 2012 var nesten halvparten av nominelt BNP (se Figur 2). Så selv om myndighetene er svært avhengige av oljeinntekter for å balansere sine budsjetter, gir dagens nivå på oljeinntektene også mulighet for høy sparing.

Figur 3 viser at de store overskuddene på offentlige budsjetter også reflekteres i driftsbalansen ovenfor utlandet. Som så ofte er tilfellet, er overskudd/underskudd på driftsbalansen og statsbudsjettet nært beslektet. ${ }^{14,15}$ Fra midten av 1980-årene til slutten av 1990årene var underskuddene problematisk store og bare mulige å opprettholde på grunn av høy sparing på 1970-tallet. Ikke før i 2000 ble balansene gjenopprettet. Som den viktigste aktøren i oljemarkedet og den eneste med relativt høy ledig produksjonskapasitet på kort sikt, spiller Saudi-Arabia en viktig rolle som markedsstabilisator, det vil si at landet er i stand til å påvirke oljeprisen ved å tilpasse hvor mye de leverer. Med sin nåværende finansielle posisjon er det åpenbart at Saudi-Arabia er 


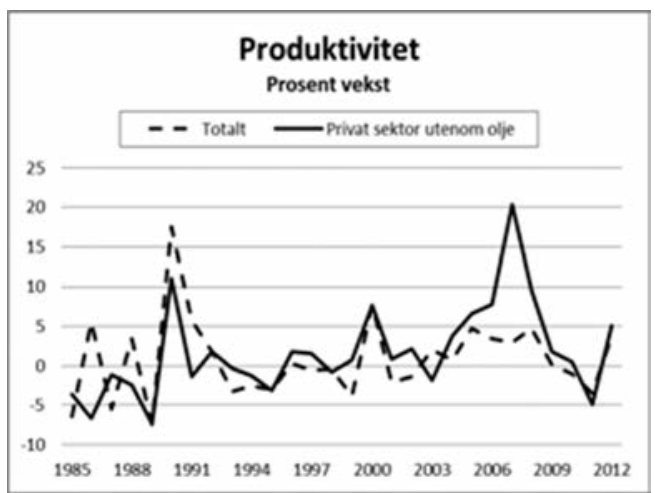

Figur 4. Kilde: Egne beregninger basert på data fra Central Department of Statistics and Information.

bedre i stand til å spille rollen som svingprodusent enn for noe år tilbake.

Til tross for at mange makroøkonomiske størrelser har utviklet seg positivt for SaudiArabia de siste årene, er målet for "saudisering" av arbeidsmarkedet, det vil si økt sysselsetting av saudiere i forhold til ikke-saudiere, ikke oppfylt. I mange år fulgte saudisk sysselsetting den totale sysselsettingen ganske tett, og på 200o-tallet lå andelen ikke-saudisk arbeidskraft ganske stabil rundt 53 prosent. I de senere årene har det vært en stor økning i sysselsettingen av ikke-saudiere og andelen saudiske sysselsatte har gått ned. Denne utviklingen har brakt andelen ikke-saudiere opp til nær 58 prosent i 2012 og myndighetenes mål ved utgangen av den niende utviklingsplanen (2014) på 53,6 prosent synes langt unna.

Sysselsettingen av ikke-saudiere har vokst til tross for en stor økning i ledigheten blant saudiske kvinner. Fra 15,8 prosent i 1999 har ledigheten blant kvinner økt jevnt til nesten 36 prosent i 2012. ${ }^{16}$ For saudiske menn derimot har ledigheten vært ganske stabil rundt 7-8 prosent. Hovedgrunnen til denne divergerende utviklingen er den sterke økningen i antall kvinner med høyere utdanning de siste 30 årene; fra 3 prosent registrerte i 1980 til 39 prosent i 2010. ${ }^{17}$ Stadig flere kvinner med høyere utdanning ønsker å arbeide, men reguleringer og praksis i det saudiske arbeidsmarkedet hindrer dem i å få passende jobber. Den skyhøye arbeidsledigheten som også rammer unge, er den største utfordringen for myndighetene og gir etter vår oppfatning også grunn for myndighetene til å frykte mulige politiske følger.

På 2000-tallet var det en markert høyere vekst $\mathrm{i}$ arbeidsproduktiviteten enn $\mathrm{i}$ de to foregående tiårene (se Figur 4). Selv om produktivitetsveksten varierer mye fra år til år, ser vi en positiv trend som skyldes sterk vekst i kapitalbeholdningen snarere enn vekst $i$ total faktorproduktivitet. Vi ser en tendens til at produktivitetsveksten avtar de siste årene, noe som kan forklares med økningen i ikke-saudisk sysselsetting. Den store økningen i bruk av lavtlønnet, ufaglært arbeidskraft fra asiatiske land skyldes rask vekst i service- og byggenæringene $\mathrm{i}$ de siste årene. Dette har resultert i lavere produktivitetsvekst. Men svakere vekst i produktiviteten i etterkant av finanskrisen i 2008 er et ganske globalt fenomen og ikke et spesielt trekk ved utviklingen i Saudi-Arabia.

\section{Den saudiske økonomien 2013-25. Et scenario}

For å diskutere robustheten av den nåværende politiske og økonomiske utviklingen i SaudiArabia har vi lagd et økonomisk scenario fram til 2025. Dette scenarioet, som hovedsakelig er basert på en videreføring av dagens trender og strukturer, kaller vi for referansebanen. For å lage denne benytter vi oss av en oppdatert og utvidet versjon av den modellen som opprinnelig ble utviklet for økonomidepartementet i Saudi-Arabia. ${ }^{18}$ Modellen er en mangesektors vekstmodell hvor sysselsetting etter sektor er inndelt i saudiere og ikke-saudiere. For ikke-saudiere er samlet 


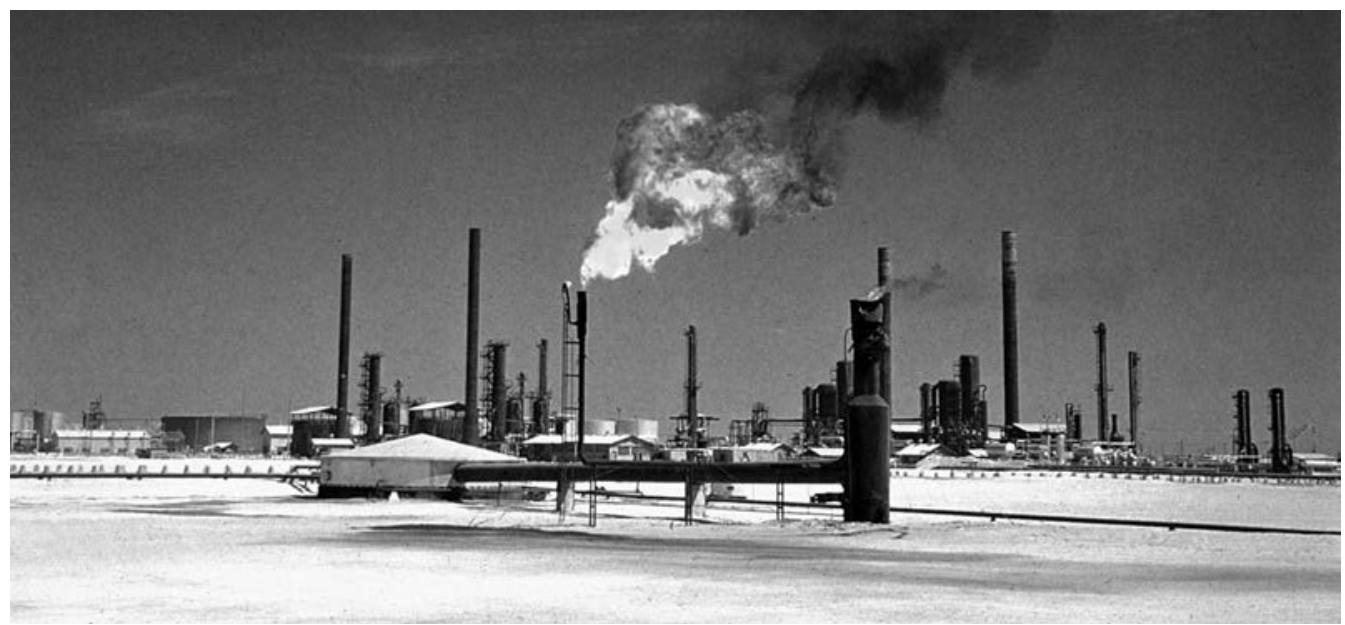

Oljesektoren dominerer den saudiske økonomien. I 2012 utgjorde produksjon av råolje og naturgass 47 prosent av BNP.

tilbud bestemt av myndighetenes regulering av arbeidstillatelser hvor lønna bestemmes slik at markedet klareres. For saudiere er det derimot lønnsstivhet slik at ledighet kan oppstå i tråd med hva vi observerer. Samlet oljeproduksjon tenkes bestemt av myndighetene, mens produksjonen i næringer utenfor olje dels avhenger av innenlandsk etterspørsel og dels av etterspørsel på verdensmarkedet. I dette avsnittet diskuterer vi de viktigste forutsetningene for analysen, og presenterer den økonomiske utviklingen i referansebanen.

Oljeprisen er den viktigste faktoren i den saudiske økonomien. Kombinasjonen av en gjennomsnittlig oljepris (Dubai dated) på 109 dollar per fat i $2012^{19}$ og høy produksjon, har resultert i et høyt BNP, og store overskudd på driftsbalansen og budsjettbalansen. Fremover forventer vi at realoljeprisen faller til go dollar i 2015 og deretter holder seg uendret nominelt slik at realoljeprisen fortsetter å falle. Vi antar at samlet oljeproduksjon øker for å dekke økt innenlandsk etterspørsel, men at eksportvolumet er om lag uendret fra 2015 til 2025. Inflasjonen på verdensmarkedet, som er anslått til 2 prosent årlig, bestemmer veksten i importprisene. Eksport utenom olje drives av etterspørselen på verdensmarkedet og av relative eksportpriser. Vi forventer at etterspørselen på verdensmarkedet tar seg opp fra 2014 og når en historisk trendvekst fra 2017.

En viktig faktor bak utviklingen i saudisk økonomi er de offentlige utgiftene. I årene 2010-2012 vokste utgiftene til offentlig konsum med henholdsvis 12, 22 og 13 prosent. ${ }^{20}$ Vekstrater som dette kan åpenbart ikke fortsette over lang tid, og tiltak ble iverksatt for å redusere utgiftsveksten i 2013. Foreløpige tall for 2013 viser en vekst i offentlig konsum på 8.8 prosent. I referansebanen antar vi at offentlig konsum vokser 4 prosent årlig, mens veksten i offentlige investeringer øker ytterligere de neste årene, før de antas å vokse i takt med befolkningen på om lag 2 prosent. Også offentlige utgifter til sosiale stønader og pensjoner har økt mye. Vi forventer at disse utgiftene vokser mindre i årene fremover, og mer i tråd med befolkningsveksten i reelle termer. Dette gir en vekst i totale offentlige utgifter på rundt 6 prosent årlig de kommende årene og en realvekst på 3-4 prosent per år, noe som innebærer en betydelig økning i det offentlige 


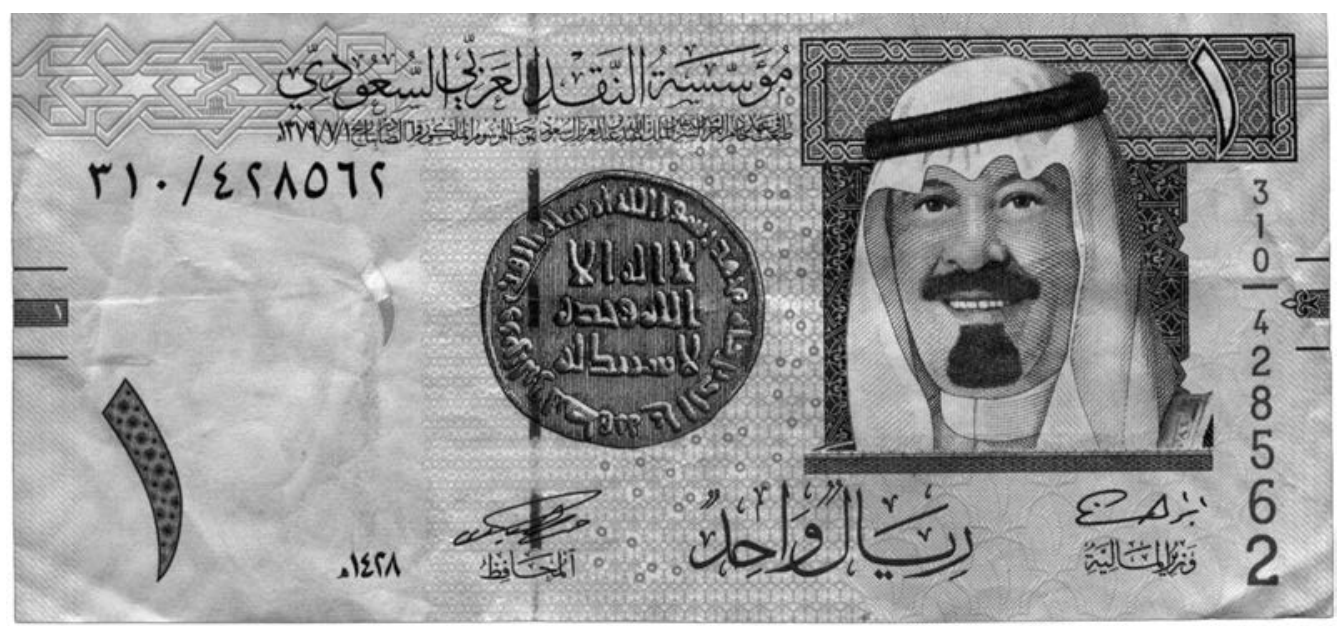

Kong Abdullah Bin Abdul-Aziz al-Saud på den saudiarabiske 1 riyal-seddelen.

tjenestetilbudet per innbygger.

Vi antar at arbeidstilbudet fra saudiere øker med tre prosent årlig frem til 2025. At økningen er større enn befolkningsveksten skyldes delvis endret alderssammensetning, men også at yngre mennesker er bedre utdannet enn sine foreldre og derfor forventes å tilby mer arbeidskraft. Spesielt blant kvinner er det nå flere med høyere utdanning, og dette vil øke deres arbeidstilbud. Som tidligere omtalt er ledigheten blant kvinner økende og har nådd et høyt nivå. Sysselsettingen av ikkesaudiere antas å vokse med 2 prosent $i$ året.

Er det rimelig å forvente at økt tilbud av saudisk arbeidskraft vil føre til økt sysselsetting av saudiere fremover? De siste årenes store investeringer i utdanning bør øke saudisk sysselsetting. Politiske reformer rettet mot arbeidsmarkedet kan også forventes å ha en effekt. Sist ute er "Nitaqat», et kvotesystem som oppmuntrer bedrifter til å ansette saudiere. Ifølge IMF vurderer myndighetene å innføre avgifter på bedrifter som ikke oppfyller Nitaqatkravene, samt å øke mulighetene for kvinnelig sysselsetting i enkelte utvalgte sektorer, som for eksempel varehandel. ${ }^{21}$ Det er også vedtatt en «jobbsøker-godtgjørelse» (Hafiz) som gir støtte til unge saudiske jobbsøkere for en ettårs periode, samt en økning i minstelønnen for saudiere i privat sektor knyttet til ansettelsessubsidier. Myndighetene stimulerer også utenlandske selskaper til å etablere produksjon i Saudi-Arabia og til å ansette saudiere.

Myndighetene har innført en ny politikk for støtte til boliginvesteringer. Nye lover, blant annet knyttet til pant i eiendom, er allerede vedtatt og ventes å øke tilgangen til boligkreditt fra private aktører. ${ }^{22}$ I tillegg gis saudiere gunstige betingelser til "førstehjemslån» gjennom Real Estate Development Fund. Summen av disse tiltakene forventes å gjøre det mulig for flere familier å kjøpe bolig. Referansebanen har derfor relativt høy vekst $i$ boliginvesteringer.

I gjennomsnitt har vi antatt moderat vekst $\mathrm{i}$ total faktorproduktivitet (den delen av BNPveksten som ikke kan forklares av vekst i bruk av arbeidskraft og realkapital) i de ulike næringene. Dette er i tråd med erfaringer der veksten i arbeidsproduktiviteten hovedsakelig tillegges kapitalfordypning, det vil si mer kapital per arbeider. 


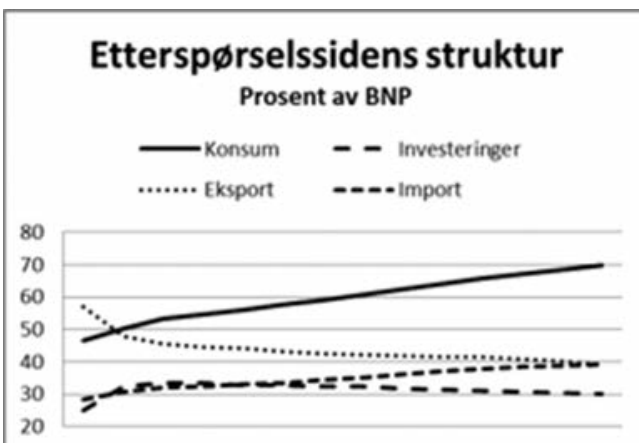

Figur 5. Etterspørsel etter hovedkategori.

Beregningene viser at $\mathrm{i}$ referansebanen avtar BNP-veksten betydelig i forhold til de høye vekstratene Saudi-Arabia har hatt de siste årene. Vi anslår en vekst på 3 prosent i 2013, ned fra nesten 7 prosent i 2012, og om lag 4 prosent årlig i perioden 2014-2025. BNP-veksten i den private ikke-oljerelaterte sektoren vil være rundt $4-4,5$ prosent i simuleringsperioden. Med en sysselsettingsvekst på om lag en prosent per år i den private ikke-oljerelaterte sektoren, vil arbeidsproduktiviteten vokse med om lag 3 prosent årlig. Dette vil presse innenlandske priser ned og bedre konkurranseevnen for saudiske bedrifter både på verdensmarkedet og hjemmemarkedet.

Referansescenarioet viser en ganske sterk nedgang i produktivitetsveksten mot slutten av simuleringsperioden. Dette skyldes at veksten i realkapitalen avtar, delvis fordi vekstimpulsene i økonomien dempes, men også fordi vi antar at kapitalkostnadene flater ut mot slutten av scenarioet. Lavere vekst i investeringene gir lavere vekst i kapitalintensiteten. Figur 5 viser de viktigste komponentene i samlet etterspørsel i referansebanen.

Økningen i samlet konsumandel reflekterer til en viss grad økningen i offentlig konsum og produksjon. Eksportens andel av BNP faller fordi volumet av oljeeksport går ned og prisen er uendret. Dette gir et fall i verdi som ikke

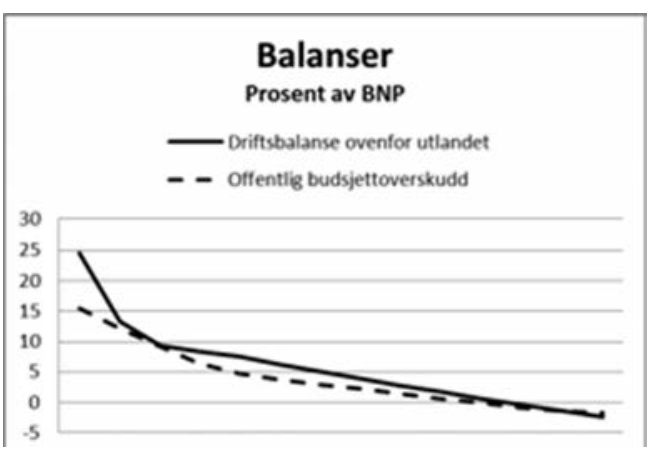

Figur 6. Driftsbalanse og offentlig budsjettoverskudd.

oppveies av økningen i eksport utenom olje. Den moderate nedgangen i investeringenes andel av BNP skyldes som nevnt over delvis noe svakere vekst, men også at kapitalkostnadene stabiliseres mot slutten av scenarioet. Den økende importandelen følger av veksten $\mathrm{i}$ innenlandsk etterspørsel og forutsetningen om moderat vekst i importprisene i tråd med fast valutakurs og moderat inflasjon på verdensmarkedet.

Figur 6 viser budsjett- og driftsbalansen som andel av nominelt BNP i referansebanen. Den viktigste grunnen til at begge avtar, og så vidt blir negative mot slutten av beregningsperioden, er forutsetningene om lavere nivå på oljeprisen, moderat vekst i oljeproduksjonen, og høy vekst i offentlige utgifter.

\section{Saudiarabisk økonomi og lavere oljepris}

I referansebanen antar vi at realoljeprisen avtar gradvis fra 109 dollar per fat i 2012 til 73 dollar per fat i 2025 , se Figur 7 . Tanken bak denne betydelige, men gradvise nedgangen i realoljeprisen er at produksjonskostnadene for ukonvensjonelle oljeressurser er estimert til å være i området 70-90 usD per fat i 2011. Siden tilbudet av olje fra disse kildene fortsatt er begrenset, men økende, vil det ta tid før det globale råoljemarkedet blir betydelig påvirket av nye oljeressurser med lavere kostnader enn 
dagens oljepris. I vårt lavpris-scenario antar vi at oppdagelsen av ukonvensjonelle ressurser vil ha en sterkere innvirkning på oljeprisen på mellomlang sikt, slik at den reelle oljeprisen fortsetter å falle markert frem til 2020, da den når 53 dollar per fat. Deretter antas realoljeprisen å være konstant. Dette innebærer at den reelle oljeprisen halveres over perioden 2012-2020. Med dette lave prisnivået er det åpenbart at mye av verdens oljeressurser blir ulønnsomme med mindre det skjer betydelige teknologiske forbedringer i oljeproduksjonen. Vi tror ikke dette er særlig sannsynlig, men et lavpris-scenario kan også skyldes lavere etterspørsel på grunn av teknologiske forbedringer i transportteknologi og nye energiressurser som vind- og solenergi.

En betydelig nedgang i realoljeprisen vil føre til lavere inflasjon og priser på verdensmarkedet, og dermed vil saudisk import bli billigere, men prisene på saudisk eksport utenom olje vil også bli lavere. I tillegg er det rimelig å anta at aktiviteten i verdensøkonomien vil øke

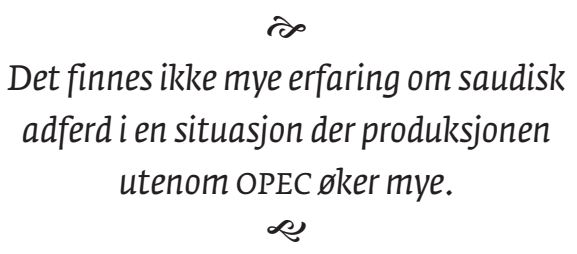

noe. Basert på eksisterende dokumentasjon fra simuleringen på globale økonomiske modeller regner vi med at aktiviteten i verdensøkonomien øker med ett prosentpoeng i 2020, mens det generelle prisnivået reduseres med ett prosentpoeng. ${ }^{23}$ Disse antagelsene innebærer elastisiteter mellom oljeprisen og BNP på -0,2 og for KPI på o,2. Dette er ganske beskjedne anslag jamført med historiske forløp, men vi tror det er nyttig å studere et alternativ der den saudiske økonomien ikke får mye drahjelp fra

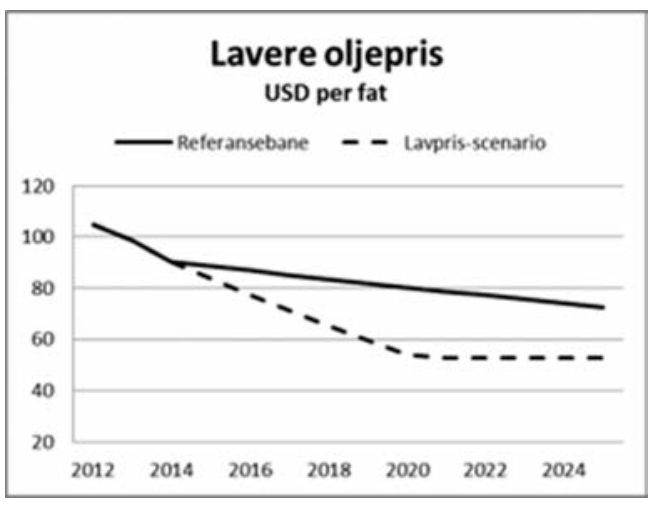

Figur 7. Realoljeprisen i referansebanen og i lavprisscenarioet. 2012-priser.

verdensøkonomien for å tilpasse seg et lavprisscenario.

To viktige spørsmål oppstår når en vil studere saudisk respons på et stort fall i oljeprisen. Først, vil det bli noen tilpasning i oljeproduksjonen? En normal reaksjon vil være å redusere produksjonen for å motvirke oljeprisfallet. Det finnes ikke mye erfaring om saudisk adferd i en situasjon der produksjonen utenom OPEC øker mye, og hvor teknologisk endring muligens vil senke etterspørselen etter olje. På den annen side kan man tenke seg at ved å godta prisen i lavpris-scenarioet, vil opEc behold sin markedsandel, mens marginale produsenter med mye høyere utvinningskostnader enn OPEC vil måtte ta støyten ved nedjusteringer i produksjonen til en situasjon med lavere global etterspørsel etter olje. I lys av disse argumentene har vi valgt å holde saudisk produksjon i lavpris-scenarioet på samme nivå som i referansebanen.

For det andre: Hvordan vil finanspolitikken bli justert som følge av mye lavere offentlige oljeinntekter? Offentlige utgifter øker reelt sett mye i referansebanen. I lavpris-scenarioet er handlingsrommet mye lavere. Hvordan skal vi da nedjustere utgiftene? Svaret avhenger åpenbart av hvor store finansielle reserver de 


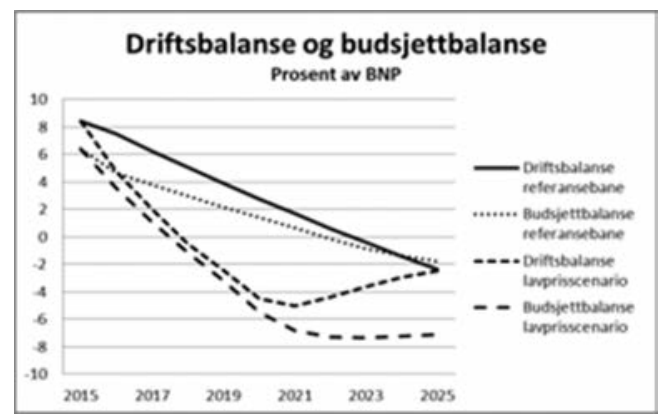

Figur 8 .

saudiske myndighetene har akkumulert i løpet av årene med høye oljepriser, se Figur 2. Med nåværende overskudd på offentlige budsjetter på nesten 10 prosent av BNP, kan budsjettene tåle noe lavere oljepris før utgifter må kuttes. Men med mye lavere oljepris er referansebanens vekst i løpende utgifter ikke bærekraftig. I lavpris-scenarioet antar vi derfor at offentlig realinvestering i infrastruktur er konstant på 2015-nivå. Videre er årlig vekst i offentlig konsum redusert fra 4 til 2 prosent, slik at utgiftene per innbygger er konstant $i$ lavprisscenarioet.

Med lavere olje- og importpriser vil konsumprisene øke mye mindre, og det er rimelig å redusere veksten i nominell lønn slik at reallønnen i hvert fall ikke er høyere i lavprisscenarioet. Siden offentlige utgifter i stor grad består av lønnskostnader, har denne justeringen en betydelig effekt på budsjettbalansen. Vi tilpasser også sosiale stønader i tråd med et lavere prisnivå og holder disse konstant i reelle termer mellom referansebanen og lavpris-scenarioet.

Driftsbalanse og offentlig budsjettbalanse i de to scenarioene er vist i Figur 8. Vi ser at driftsbalansen, etter å ha ligget betydelig lavere, gradvis går mot null fra 2020 da nedgangen i realprisen på olje flater ut, og at underskuddene på driftsbalansen slett ikke er

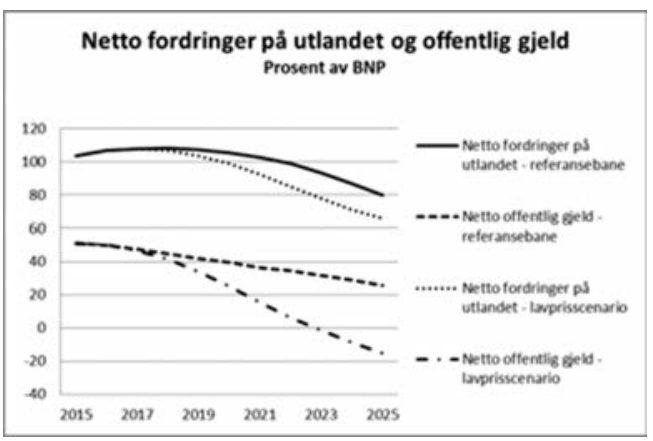

Figur 9. Netto fordringer og netto offentlige finansielle eiendeler.

alarmerende. Eksport utenom olje stimuleres av høyere etterspørsel på verdensmarkedet og bidrar positivt til driftsbalansen. Økningen i importutgiftene avtar også, dels på grunn av lavere etterspørsel og produksjon i saudisk økonomi, men også fordi prisene på verdensmarkedet er lavere i lavpris-scenarioet.

Figur 9 viser at netto utenlandske eiendeler (netto fordringer på utlandet) fortsatt er positive i 2025, og selv om vi ikke har gjort simuleringer etter 2025 ser det ut til at nedgangen som andel av BNP avtar når vi nærmer oss 2025. Som vist i Figur 8, reverseres underskuddet på budsjettbalansen så vidt når vi nærmer oss 2025. Likevel kan ikke et budsjettunderskudd på syv prosent av BNP vedvare over lang tid, selv om netto offentlige gjeld ikke viser noen alarmerende trend. Hvis man mener budsjettunderskuddene er for store i lavpris-scenarioet, må responsen være enten å kutte ytterligere i offentlige utgifter, eller å innføre beskatning $i$ en eller annen form, eller i det minste å kutte subsidiene på bensin. Det siste er under vurdering, men her oppfatter myndighetene at de har beskjedent politisk spillerom og ingenting har foreløpig skjedd. Mens man med dagens høye priser har råd til å kompensere forbrukerne med økte utgifter på andre områder dersom man kuttet i subsidiene på bensin, er nok evnen til å gjøre noe tils- 


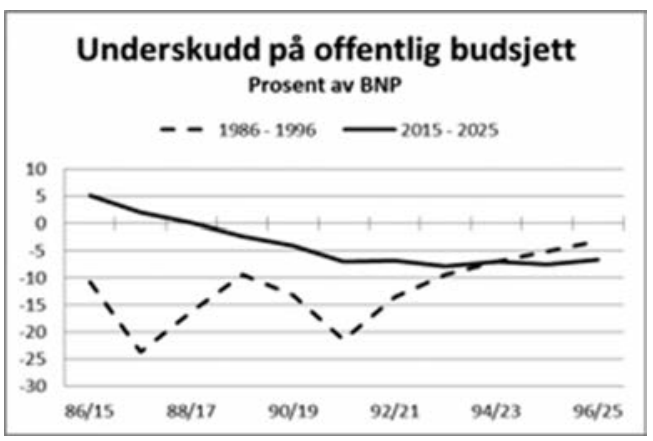

Figur 10. Underskudd på offentlig budsjett. 1986-1996 faktisk og 2015-2025 simulert.

varende $i$ en mer krisepreget økonomisk situasjon som i lavpris-scenarioet, liten.

Lavpris-scenarioet illustrerer at en realpris på olje ned mot 50 dollar per fat representerer store tap for Saudi-Arabia, men fører likevel ikke til økonomiske problemer som ligner på det mange europeiske land har opplevd siden 2009.

Reduksjonen i offentlige utgifter vil føre til lavere økonomisk aktivitet. Dette vil igjen føre til lavere inntekt for husholdningene som vil redusere konsumet og bidra til redusert BNP i private sektor utenom olje. På den annen side vil den kostnadsmessige konkurranseevnen for produsentene utenom oljeindustrien forbedres, og de vil oppleve høyere etterspørsel på verdensmarkedet. Dette vil stimulere til økt produksjon, særlig i sektorer som produserer for eksport. Derfor vil privat sektors BNP rammes mindre enn samlet BNP. Dette skyldes at offentlig sektor, som reduseres betydelig, er inkludert i tallene for total BNP.

Med lavere produksjon følger lavere etterspørsel etter arbeidskraft. Med mindre arbeidstilbudet reduseres tilsvarende vil arbeidsledigheten blant saudiere øke. En kunne tenke seg at mesteparten av justeringen i arbeidsmarkedet falt på ikke-saudisk arbeidskraft, men det er urimelig å anta, fordi vi i lavpris-scenarioet hovedsakelig får lavere aktivitet

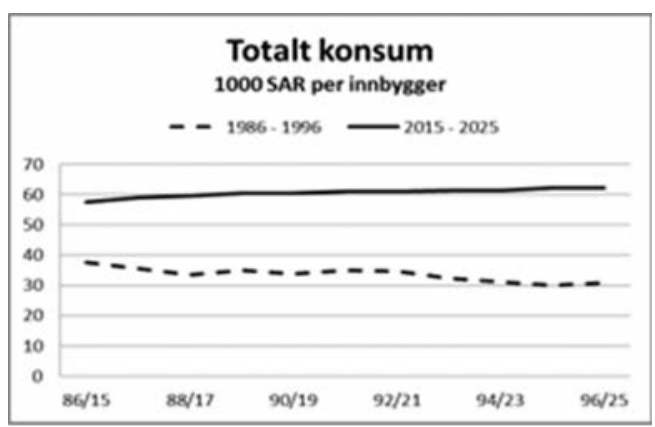

Figur 11. Konsum per innbygger i to lavprisscenarier.

i offentlig sektor som for det meste sysselsetter saudisk arbeidskraft. Dermed er det sannsynlig at arbeidsledigheten blant saudiere vil øke i lavpris-scenarioet. Sammenlignet med referansebanen hvor arbeidsledigheten blant saudiere synker fra 11.5 prosent i 2015 til om lag 4 prosent i 2025, er lavpris-scenarioet preget av vedvarende høy arbeidsledighet på rundt 13-14 prosent.

Den alarmerende utviklingen i arbeidsledigheten blant saudiere kunne nok sett lysere ut hvis mer vellykkede reformer av arbeidsmarkedet ble gjennomført. I vår referansebane har vi allerede antatt reformer som fører til noe saudisering av arbeidsmarkedet fremover. Det er mulig å oppnå mer enn vi har lagt til grunn, og i så fall ville økningen i saudisk arbeidsledighet bli mindre enn det som er skissert over. Politisk sett kan en høy arbeidsledighet være det mest problematiske aspektet ved lavpris-scenarioet, fordi kuttene i offentlige utgifter ikke egentlig er så store og gjøres fra ganske høye nivåer.

\section{Oljeprissjokket i 1985/86}

I løpet av vinteren 1985/86 ble prisen på råolje halvert. Konsekvensene av det plutselige oljeprisfallet var en stor økning i underskuddene på driftsbalansen og på offentlige budsjetter, både i Saudi-Arabia og flere andre opec-land. 
Figur 10 viser faktiske budsjettunderskudd i perioden 1986-1996 og simulerte underskudd i perioden 2015-2025 i henhold til lavprisscenarioet beskrevet over. Vi ser at det var større underskudd i perioden 1986-1996, og de akkumulerte effektene var betydelige. I lavpris-scenarioet er budsjettsituasjonen langt bedre, spesielt i begynnelsen av perioden. Dette skyldes delvis den gradvise nedgangen i oljeprisen i motsetning til sjokket i 1985/86, men også forskjeller i måten den saudiske økonomien tilpasser seg lavere pris i forhold til for 25 år siden.

Figur 11 viser at mens forbruket per innbygger falt over en lang periode etter oljepriskollapsen i 1985/86, innebærer lavprisscenarioet fortsatt stigende materiell levestandard. Dette skyldes delvis våre forutsetninger om beskjedne kutt i offentlige utgifter, dog med en kostnad i form av ganske store budsjettunderskudd mot slutten av simuleringsperioden, samt høy arbeidsledighet.

\section{Konklusjon}

Drevet av høye oljepriser og store overskudd på offentlige budsjetter og driftsregnskapet overfor utlandet, har den saudiske økonomien vokst raskt i flere år. Mye av overskuddene er spart og Saudi-Arabia har akkumulert betydelige finansielle fordringer de siste årene. Dette gjør økonomien mer robust overfor fremtidige oljeprissjokk. Den positive økonomiske utviklingen kan også delvis forklare hvorfor Saudi-Arabia ikke har opplevd politisk uro lik andre land i regionen. Høyt på den politiske dagsorden står nå den relativt høye arbeidsledigheten, spesielt for saudiske kvinner. En rekke politiske tiltak er rettet mot arbeidsmarkedet for å få til mer saudisering.

Vi har konstruert en referansebane ved modellsimuleringer på en stor makromodell for å studere om dagens trender og politiske til- tak er bærekraftige gitt en moderat, men over tid ganske betydelig nedgang i oljeprisen. Ifølge våre simuleringer kan både økonomisk vekst og saudisk sysselsetting øke i mange år uten å sette finansielle balanser på spill. Med vårt anslag på oljeprisen ser den saudiske økonomien ganske robust ut, spesielt sammenlignet oljeprissjokket for 25 år siden.

For å undersøke sårbarheten i den saudiske økonomien ved et dramatisk fall i oljeprisen, har vi også gjort simuleringer der oljeprisen faller til omtrent halvparten av nivået i 2012. Dette ligner på fallet i oljeprisen på midten av 1980-tallet. Vi antar at offentlige utgifter per innbygger kuttes slik at de blir konstante i reelle termer. Dette scenarioet medfører riktignok store budsjettunderskudd, men kun omtrent halvparten av hva man opplevde på slutten av 1980-tallet og begynnelsen av 1990tallet. I tillegg kan dette oppnås uten nedgang i reelt forbruk per innbygger. Tiltaket har imidlertid en kostnad i form av mye høyere arbeidsledighet blant saudiere $i$ forhold til i referansebanen. I så måte bør de politiske prioriteringene være å øke yrkesdeltakelsen og sysselsettingen av saudiere, noe som har stått høyt på regjeringens dagsorden i minst to tiår. De svake resultatene på dette området så langt gir grunn til bekymring hvis man skal betrakte det saudiske samfunnet $i$ et lengre tidsperspektiv enn hva vi har gjort her. Mangel på jobbmuligheter for unge er kanskje den største politiske trusselen mot regimestabilitet. ${ }^{24}$

\section{$\cdot f \cdot$}

1 Althani, Mohamed A.J. (2012), The Arab Spring o The GulfStates-Time To Embrace Change, Profile Books Ltd, London, UK.

2 Andersen, J.J., and S. Aslaksen (2013) «Oil and political survival», Journal of Development Economics, (100), 89106.

3 Ploeg, F. van der (2011), Natural Resources: "Curse of Blessing", Journal of Economic Literature,(49), 366-420. 
4 Cappelen, $\AA$. and R. Choudhury (2004), «The Future of the Saudi Arabian Economy: Possible Effects on the World Oil Market", pp. 41- 62 in D. Heradstveit and H. Hveem, Oil in the Culf, Ashgate, Hants, England.

5 Cappelen, $\AA$. and R. Choudhury (2005), «Saudi-Arabia økonomisk politikk under politisk usikkerhet», Internasjonal politikk, 63, 371-394.

6 IMF database per juni 2013.

7 IMF database per juni 2013.

8 World Bank (2013), World Development Indicators, 2013, Washington.

9 Bowers, M. (2013), "The Rentier Dilemma of Development: A Comparison of Economic Diversification in Saudi Arabia and Abu Dhabi, pp. 64-87 i World Outlook - An Undergraduate Journal of International Affairs, Fall 2013 Issue 44.

10 Malik, A., and B. Awadallah (2013), "The Economics of the Arab Spring», World Development (45), 296-313.

11 "Gross Domestic Product by Kind of Economic Activity at 1999 Constant Prices», http://www.cdsi.gov.sa/english/ index.php?option=com_docman\&Itemid $=151$, Central Department of Statistics and Information.

12 The Eight Development Plan 1424-1430 H, (2005-2009), Ministry of Economy \& Planning, Kingdom of Saudi Arabia, 2005.

13 SAMA (2013), Saudi Arabian Monetary Agency, Forty Ninth Annual Report, Latest Economic Developments, $1434 \mathrm{H}$ (2013 G).

14 Miller, S.M. and Russek, F.S. (1989), "Are the twin deficits really related?» Contemporary Economic Policy, (7), 91-115.

15 Kumhof, M. and Laxton, D. (2013), "Fiscal deficits and current account deficits», Journal of Economic Dynamics and Control, Volume 37, Issue 10, October 2013, Pages 2062-2082.

16 Central Department of Statistics and information (various Manpower Research Bullentin's).

17 Patterson, K. (2013), Education and Female Labor Market Participation in the Middle East: A Case Study of Turkey and Saudi Arabia, Department of International Affairs, University of Colorado at Boulder Spring 2013.

18 Cappelen, A. and R. Choudhury (2004), "The Future of the Saudi Arabian Economy: Possible Effects on the World Oil Market", pp. 41- 62 in D. Heradstveit and H. Hveem, Oil in the Culf, Ashgate, Hants, England.

19 BP Statistical Review of World Energy June 2013 bp.com/statisticalreview.

20 CDSI (2013), National Account Indicators 2013 (1434/1435), Central Department of Statistics \& Information, Saudi Arabia.

21 IMF (2013b), Saudi Arabia, 2013 Article IV Consultation, IMF Country Report No. 13/229, July 2013, IMF, Washington, D. C.

$22 \operatorname{IMF}$ (2013b), Saudi Arabia, 2013 Article IV Consultation, IMF Country Report No. 13/229, July 2013, IMF, Washington, D. C.
23 OECD (2011), Economic Outlook, Vol. 2011, Issue 1, No. 89, OECD, Paris.

24 Malik, A., and B. Awadallah (2013), "The Economics of the Arab Spring», World Development (45), 296-313. 